\title{
How SARS-CoV-2 might affect potassium balance via impairing epithelial sodium channels?
}

\author{
Maryam Noori ${ }^{1} \cdot$ Seyed Aria Nejadghaderi ${ }^{2,3} \cdot$ Mark J. M. Sullman ${ }^{4,5} \cdot$ Kristin Carson-Chahhoud $^{6,7}$. \\ Mohammadreza Ardalan ${ }^{8} \cdot$ Ali-Asghar Kolahi $^{9} \cdot$ Saeid Safiri $^{10,11}$ (D)
}

Received: 14 May 2021 / Accepted: 10 August 2021 / Published online: 15 August 2021

(C) The Author(s), under exclusive licence to Springer Nature B.V. 2021

\begin{abstract}
Severe acute respiratory syndrome coronaviruses 2 (SARS-CoV-2) is the causative agent of current coronavirus disease 2019 (COVID-19) pandemic. Electrolyte disorders particularly potassium abnormalities have been repeatedly reported as common clinical manifestations of COVID-19. Here, we discuss how SARS-CoV-2 may affect potassium balance by impairing the activity of epithelial sodium channels (ENaC). The first hypothesis could justify the incidence of hypokalemia. SARS-CoV-2 cell entry through angiotensin-converting enzyme 2 (ACE2) may enhance the activity of renin-angiotensin-aldosterone system (RAAS) classical axis and further leading to over production of aldosterone. Aldosterone is capable of enhancing the activity of $\mathrm{ENaC}$ and resulting in potassium loss from epithelial cells. However, type II transmembrane serine protease (TMPRSS2) is able to inhibit the $\mathrm{ENaC}$, but it is utilized in the case of SARS-CoV-2 cell entry, therefore the ENaC remains activated. The second hypothesis describe the incidence of hyperkalemia based on the key role of furin. Furin is necessary for cleaving both SARS-CoV-2 spike protein and ENaC subunits. While the furin is hijacked by the virus, the decreased activity of $\mathrm{ENaC}$ would be expected, which causes retention of potassium ions and hyperkalemia. Given that the occurrence of hypokalemia is higher than hyperkalemia in COVID-19 patients, the first hypothesis may have greater impact on potassium levels. Further investigations are warranted to determine the exact role of ENaC in SARS-CoV-2 pathogenesis.
\end{abstract}

Keywords Electrolytes $\cdot$ Serum potassium $\cdot$ Hypokalemia $\cdot$ Hyperkalemia $\cdot$ COVID-19 $\cdot$ SARS-CoV-2 $\cdot 2019-n C o V \cdot$ Epithelial sodium channels $\cdot \mathrm{ENaC}$

Ali-Asghar Kolahi

a.kolahi@sbmu.ac.ir

Saeid Safiri

safiris@tbzmed.ac.ir

1 Student Research Committee, School of Medicine, Iran University of Medical Sciences, Tehran, Iran

2 School of Medicine, Shahid Beheshti University of Medical Sciences, Tehran, Iran

3 Systematic Review and Meta-Analysis Expert Group (SRMEG), Universal Scientific Education and Research Network (USERN), Tehran, Iran

4 Department of Social Sciences, University of Nicosia, Nicosia, Cyprus

5 Department of Life and Health Sciences, University of Nicosia, Nicosia, Cyprus
6 Australian Centre for Precision Health, University of South Australia, Adelaide, Australia

7 School of Medicine, University of Adelaide, Adelaide, Australia

8 Kidney Research Center, Tabriz University of Medical Sciences, Tabriz, Iran

9 Social Determinants of Health Research Center, Shahid Beheshti University of Medical Sciences, Tehran, Iran

10 Tuberculosis and Lung Disease Research Center, Tabriz University of Medical Sciences, Tabriz, Iran

11 Social Determinants of Health Research Center, Department of Community Medicine, Faculty of Medicine, Tabriz University of Medical Sciences, Tabriz, Iran 


\section{Introduction}

The current pandemic of coronavirus disease 2019 (COVID-19) caused by severe acute respiratory syndrome coronaviruses 2 (SARS-CoV-2) have affected more than 191 million people worldwide with a total mortality of 4.1 million as of 23 July 2021 [1].

Electrolyte abnormalities are common manifestations of the disease and are substantially attributed to poor prognosis $[2,3]$. Recently, the prevalence of mild hypokalemia (serum potassium $<3.5,>3 \mathrm{mmol} / \mathrm{L}$ ) and severe hypokalemia (serum potassium $<3 \mathrm{mmol} / \mathrm{L}$ ) were estimated to be $37 \%$ and $18 \%$, respectively, in patients with COVID-19 [4] and it was significantly associated with intensive care units admission and requirement of invasive mechanical ventilation [5]. On the other hand, hyperkalemia was determined to occur in $10.3 \%$ of patients and it was associated with increased risk of 30-day mortality [6]. Therefore, the high prevalence of potassium disorders may have a potential relationship with the natural history of SARSCoV-2. Understanding and investigating the clinical manifestations of COVID-19 could provide insights into the pathophysiological features of this emerging virus. As a result, we will review the current literature on the roles of renin-angiotensin-aldosterone system (RAAS) and epithelial $\mathrm{Na}^{+}$channels $(\mathrm{ENaC})$ on serum potassium levels affected by SARS-CoV-2 infection.

\section{SARS-CoV-2 and RAAS}

The coronavirus spike protein plays a fundamental role in the early stages of the SARS-CoV-2 infection, which contains a $\mathrm{S} 1$ domain responsible for receptor binding and a S2 domain mediating membrane fusion [7]. The S1-spike protein interacts with angiotensin-converting enzyme 2 (ACE2), a part of the RAAS, which is known as a multi-hormonal system, having a profound impact on the maintenance of electrolyte balance and blood pressure regulation $[8,9]$. The RAAS is defined as a two-arm, counter-regulatory system and is divided into classical and alternative axes [10].

In the classical axis, Angiotensin I (Ang I) is generated by the cleavage of a precursor peptide called angiotensinogen, and then is converted to Angiotensin II (Ang II) by ACE [10]. Ang II attaches to Ang II type 1 receptors (AT1R) and as a result, the ACE/Ang II/AT1R axis induces acute lung failure and also triggers aldosterone release from the adrenal gland $[11,12]$. Along this pathway, Ang II activates Ang II type 2 receptors (AT2R), which have the opposite effects to Ang II/AT1R and acts to resolve inflammation, but AT2R expression is significantly lower during the human lifespan, except at the neonatal stage $[10,13]$.
In the alternative axis, RAAS is balanced by ACE2, which is a homologue of ACE [14]. ACE2 can transform Ang II to Angiotensin 1-7 (Ang 1-7) and convert Ang I to Angiotensin 1-9, which can be further converted to Ang 1-7 [10]. Ang 1-7 is a specific Mas receptor (MasR) agonist and plays a central role in the alternative axis of the RAAS, ACE2/Ang 1-7/MasR [10]. Binding Ang 1-7 to MasR exerts several protective effects, such as antioxidative, antiinflammatory, and antifibrotic effects, in addition to decreasing aldosterone secretion $[15,16]$. As a consequence, potential tissue injury depends on the balance between these two opposing pathways [10].

As abovementioned, SARS-CoV-2 enters human cells via ACE2 [8]. It has been shown that the expression of ACE2 would be reduced upon coronavirus infection [12]. Since RAAS is based upon a dynamic equilibrium between two opposite axes, the down-regulation of ACE2 leads to enhanced activity of the RAAS classical axis, which further promotes the internalization of ACE2 and results in a vicious circle of imbalance (Fig. 1) [10, 17]. We continue to discuss two hypotheses that explain how COVID-19 might affect serum potassium levels via $\mathrm{ENaC}$.

\section{Depleted potassium levels and $\mathrm{ENaC}$ hyperactivity}

The over-activation of the $\mathrm{ENaC}$ plays a crucial role in urinary potassium loss and subsequently reduced serum potassium levels [18]. Interestingly, ENaC and ACE2 expression share similar distributions in the tissues, including renal tubules, urinary bladder, colon epithelium, lung airway, and alveoli $[19,20]$. This channel modulates salt reabsorption and balances electrolyte homeostasis. ENaC activity is facilitated via a variety of factors, particularly aldosterone levels [20]. The over stimulation of the ACE/Ang II/ AT1R axis, during the SARS-CoV-2 infection, may result in $\mathrm{ENaC}$ hyperactivity. Indeed, aldosterone, whose secretion is promoted by Ang II, binds to mineralocorticoid receptors and leads to the upregulation and enhanced activity of the $\mathrm{ENaC}$ [21]. Furthermore, Ang II has been shown to significantly improved $\mathrm{ENaC}$ activity via binding to AT1R [22]. ENaC function leads to increase in sodium reabsorption from luminal fluid, resulting in an accumulation of an intracellular positive charge [20]. Subsequently, the $\mathrm{Na}^{+} / \mathrm{K}^{+}$ ATPase pump on the basolateral border pumps intracellular sodium into the interstitium, in exchange for potassium. In turn, potassium exits the apical membrane through transport pathways, such as the renal outer medullary potassium (ROMK) channels and the $\mathrm{Ca}^{2+}$-activated $\mathrm{K}^{+}(\mathrm{BK})$ channels, causing kaluresis in the context of $\mathrm{ENaC}$ hyperactivity in the distal convoluted tubules [23].

Moreover, after the SARS-CoV-2 binds to the ACE2 receptor, the $\mathrm{S}$ protein is cleaved by host cell surface proteins, called type II transmembrane serine protease 


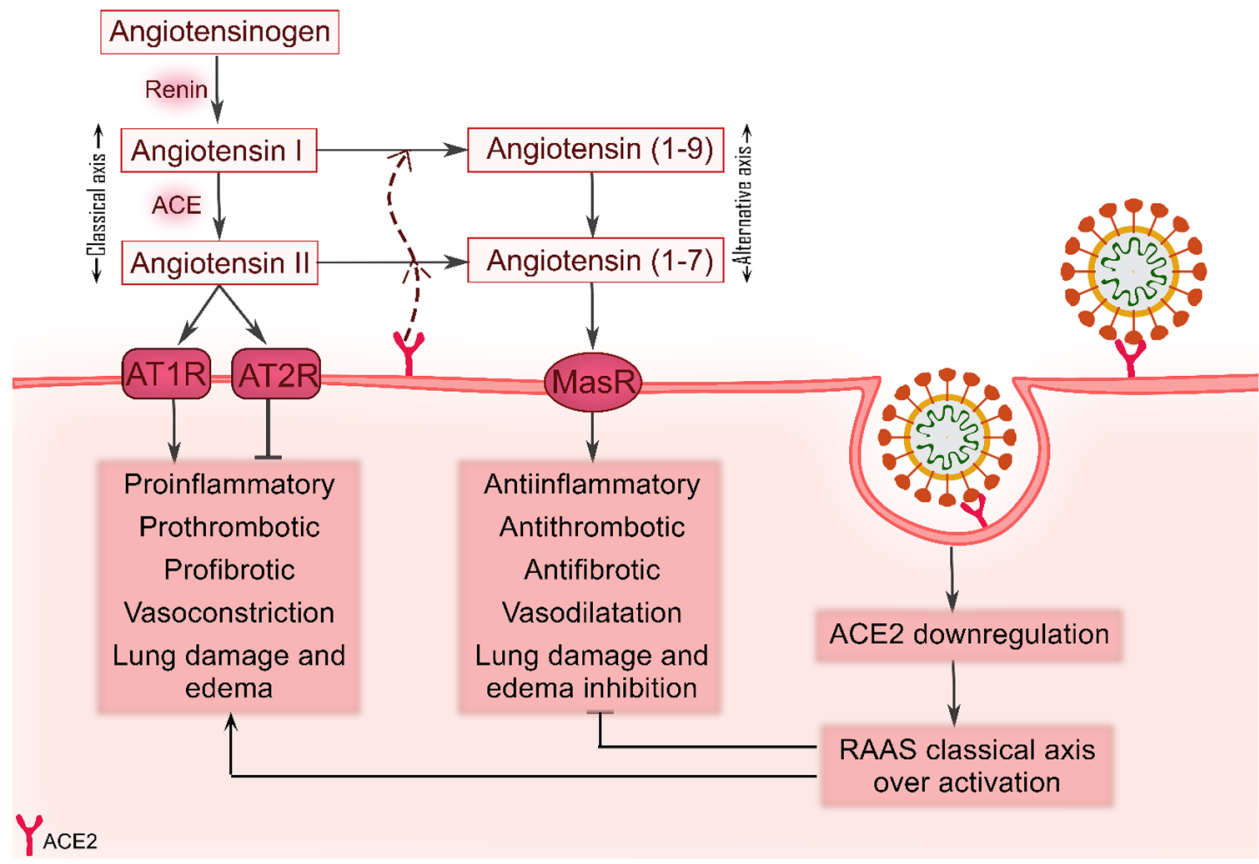

Fig. 1 Schematic of the possible role of RAAS in SARS-CoV-2 pathogenesis. Angiotensin I is generated through the action of renin on a precursor protein, Angiotensinogen. In the RAAS classical axis, ACE converts Angiotensin I to angiotensin II, leading to inflammation, thrombosis, fibrosis, vasoconstriction, and lung injury. Conversely, in the RAAS alternative axis, ACE2 inactivates Angiotensin II by producing Angiotensin (1-7), which induces biological activity distinct from Angiotensin II through binding with MasR. In the con-

(TMPRSS2), which facilitates viral fusion and cell entry [24]. TMPRSS2 expression is modulated by a guanine rich sequence which is capable of forming G-quadruplex structure in the promoter region of this gene [25]. Intracellular potassium ions can stabilize the G-quadruplex structure, hence down-regulating TMPRSS2 expression and impairing viral cell entry [25]. ENaC hyperactivity, due to ACE/ Ang II/AT1R over stimulation results in intracellular loss of potassium, so leads to high expression of TMPRSS2 [18]. In an inhibitory feedback loop, TMPRSS2 can reduce $\mathrm{ENaC}$ activity, whereas in the case of COVID-19, ENaC remains activated without inhibition by TMPRSS2, because TMPRSS2 is utilized for viral cell entry mechanisms (Fig. 2, right panel) $[18,26]$.

To further support the importance of the previous hypothesis on the severity of COVID-19 infection, we discuss the role of the NLR family pyrin domain containing 3 (NLRP3) inflammasome, which is one of the main intracellular inflammatory pathways of the innate immune system [27]. An unrestricted immune reaction in SARS-CoV-2 pathogenesis, known as the "cytokine storm", leads to extensive tissue damage [28]. Interleukin (IL)-1 $\beta$ and IL-18 are two types of cytokines that are activated by NLRP3 [27]. In 2007, Pe'trilli et al. revealed that potassium efflux is the common text of SARS-CoV-2 infection, the ACE-2 would be downregulated, thus mediating over activation of the RAAS classical axis. RAAS Renin angiotensin aldosterone system, $A C E$ angiotensin-converting enzyme, $A C E 2$ angiotensin-converting enzyme 2, Mas $R$ mas receptor, $A T 1 R$ angiotensin II type 1 receptor, $A T 2 R$ angiotensin II type 2 receptor, $S A R S-C o V-2$ severe acute respiratory syndrome coronavirus 2

and specific trigger of NLRP3 activation [29]. Therefore, potassium excretion, in the context of $\mathrm{ENaC}$ hyperactivity, may induce NLRP3 over activation, resulting in exacerbation of inflammatory responses and poor clinical outcomes [30-34]. Ultimately, according to this hypothesis, ENaC over stimulation, due to viral-mediated ACE2 downregulation, induces the loss of potassium from epithelial cells, which may cause low serum potassium concentration.

\section{Elevated potassium levels and $\mathrm{ENaC}$ hypoactivity}

The second hypothesis describes the role of furin, a type of proprotein protease, which is an important reason for the higher infectivity of SARS-CoV-2, compared with other coronaviruses $[35,36]$. Furin facilitates the binding of the virus to ACE2 by cleaving its Spike protein [37]. In addition, furin is necessary for activating the $\mathrm{ENaC}$ by cleaving its $\alpha$-subunit at two cleavage sites [38]. Recent research has shown that the furin cleavage site of the SARS-CoV-2 spike protein is identical to the furin-cleavable peptide sequence on the $\mathrm{ENaC} \alpha$-subunit [39]. Indeed, furin is essential to the activity and expression of $\mathrm{ENaC}$, but in this instance, it is hijacked by SARS-CoV-2, creating competition for furin use following infection with the virus [40]. Without 


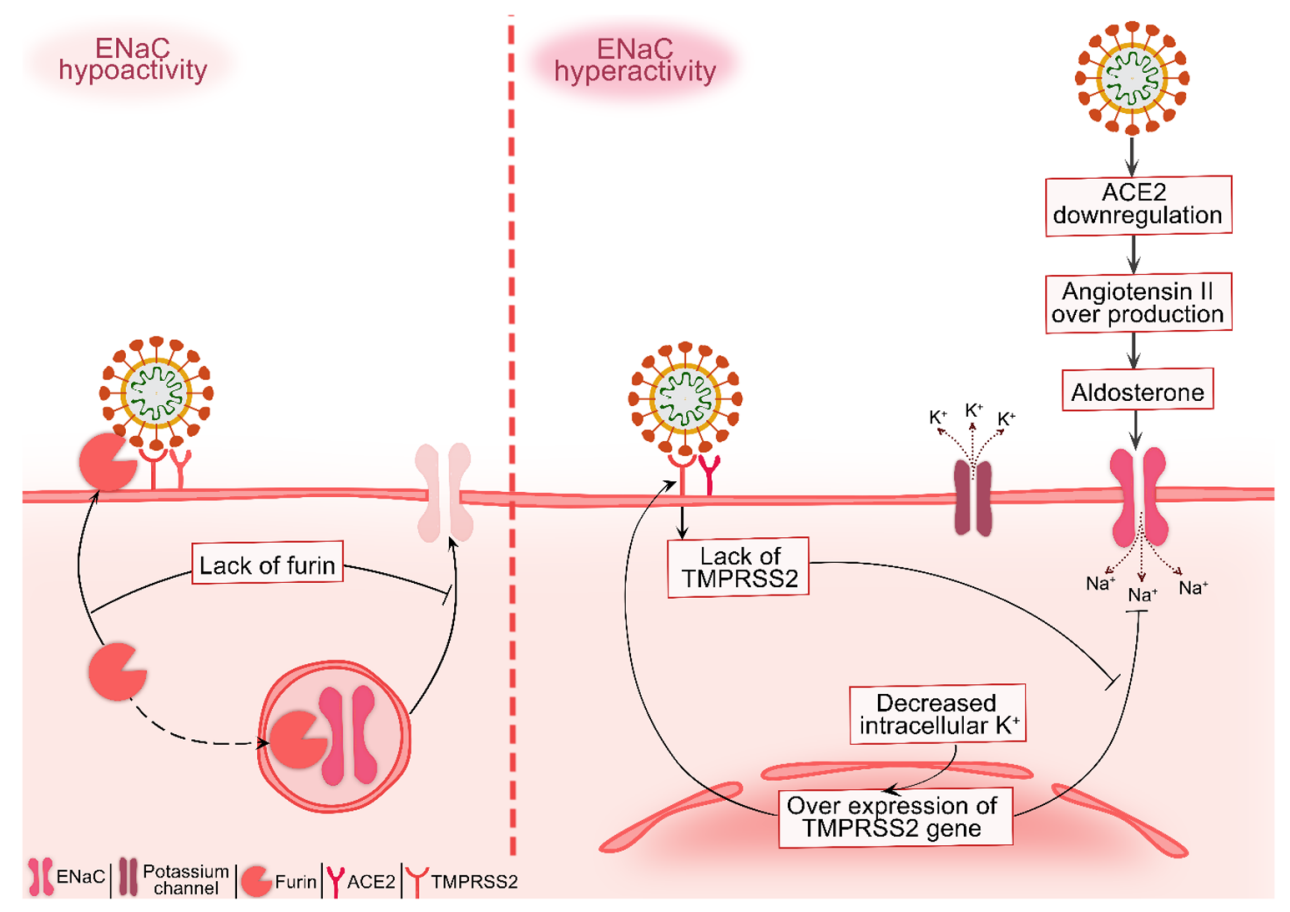

Fig. 2 Schematic of the hypothetical impact of SARS-CoV-2 infection on ENaC. Over activation of the RAAS classical axis leads to the stimulation of aldosterone secretion. Aldosterone enhances the activity of $\mathrm{ENaC}$ in the apical cell membrane, which results in the excretion of potassium out of the cell and into the luminal space. Decreased intracellular potassium induces the TMPRSS2 gene to be over expressed. TMPRSS2 is capable of inhibiting ENaC activity, which would be utilized by SARS-CoV-2 and so ENaC remains acti- vated (right panel). SARS-CoV-2 spike protein harbors a furin cleavage site which is similar to the $\mathrm{ENaC}$ furin-cleavable peptide. Furin is hijacked by SARS-CoV-2, meaning the ENaC cannot be assembled and become hypoactivated (left panel). RAAS Renin angiotensin aldosterone system, ENaC epithelial sodium channel, ACE2 angiotensin-converting enzyme 2, TMPRSS2 type II transmembrane serine protease, $S A R S-C o V-2$ severe acute respiratory syndrome coronavirus 2 furin-mediated cleavage, a decreased in the efficacy of $\mathrm{ENaC}$ is likely (Fig. 2, left panel). This may have a negative effect on epithelial cells and disturb the water or electrolyte homeostasis, leading to elevated serum potassium levels. $\mathrm{ENaC}$ dysfunction may be better understood by studying its genetic disorders. Pseudohypoaldosteronism is a condition in which $\mathrm{ENaC}$ subunits undergo a loss of function mutation, typically manifested by hyperkalemia, metabolic acidosis, and hypertension [41]. Furthermore, ENaC plays a critical role in lung fluid clearance, meaning that reduced $\mathrm{ENaC}$ activity may explain why patients with COVID-19 sometimes die of severe pulmonary edema [40, 42].

\section{Interaction between emerging SARS-CoV-2 therapeutic agents and ENaC activity}

In recent months, several promising therapeutic approaches have been developed [43]. While membrane-bound ACE2 facilitates SARS-CoV-2 cell entry, a modified form of soluble ACE2, called human recombinant soluble ACE2 (hrsACE2), could competitively bind to the virus, which should theoretically be beneficial in the treatment of
COVID-19 [44]. Indeed, binding hrsACE2 to the spike protein may mediate SARS-CoV-2 neutralization and rescue cellular ACE2 activity, which have been linked to protecting multiple organs from injury by reducing Ang II levels [45]. As the RAAS equilibrium shifts to the alternative axis, normalization of $\mathrm{ENaC}$ activity would be feasible. In addition to hrsACE2, protease inhibitors capable of reducing TMPRSS2 activity are among the novel therapeutics under development [46]. Camostat mesilate, a TMPRSS2 blocker, has been shown to inhibit SARS-CoV-2 infection [47]. In addition to its antiviral activity, Camostat mesilate is well-known for its anti-hypertensive properties and renoprotective effects, since it reduces the activity of plasmin which cooperates with furin in cleaving and subsequently activating the ENaC [48-50]. Considering the inhibitory impact of TMPRSS2 on ENaC, camostat mesilate would be able to enhance ENaC activity by blocking TMPRSS2, but blocking of plasmin activity may impair the $\mathrm{ENaC}$ activity. Therefore, this paradoxical issue will be resolved through further investigations measuring the net effect of camostat mesilate on ENaC activity in the context of SARS-CoV-2 infection. Bromhexine, a potential therapeutic option, is another blocker of TMPRSS2 enzyme with ENaC blocking 
effects [51]. Finally, furin is a potential therapeutic target for COVID-19 and furin inhibitors are assumed to reduce ENaC assembly and impair electrolyte balance [52, 53]. In summary, whatever new therapy emerges for treating COVID19 , dealing with the disruption to the patients' electrolyte homeostasis is vital.

\section{Conclusion}

SARS-CoV-2 can lead to both decreases and increases in serum potassium levels. As previously mentioned, the prevalence of hypokalemia is higher in patients with COVID-19, so it seems that the first hypothesis has a stronger impact on potassium abnormalities, and since most patients show mild degrees of potassium depletion, the second hypothesis might act as a mitigator of the first. Further molecular investigations are warranted in order to clarify the exact role of $\mathrm{ENaC}$ in SARS-CoV-2 pathogenesis.

Acknowledgements We would like to thank the support of Social Determinants of Health Research Center, Shahid Beheshti University of Medical Sciences, Tehran, Iran.

Author contributions $\mathrm{MN}$ and SAN designed and wrote the first draft of the manuscript; MJMS, KCC, MRA, AAK, and SS critically revised the manuscript. All authors reviewed and approved the final version of the manuscript.

Funding The present study was supported by Shahid Beheshti University of Medical Sciences, Tehran, Iran (Grant No. 24495).

Data availability Not applicable.

Code availability Not applicable.

\section{Declarations}

Conflict of interest The authors declare that there is no conflict of interests.

Ethical approval No ethical approval required for this article.

Consent for publication Not applicable.

Consent to participate Not applicable.

\section{References}

1. World Health Organization (2021) WHO coronavirus disease (COVID-19) dashboard. WHO. https://covid19.who.int. Accessed 25 July 2021

2. Sarvazad H, Cahngaripour SH, Eskandari Roozbahani N, Izadi B (2020) Evaluation of electrolyte status of sodium, potassium and magnesium, and fasting blood sugar at the initial admission of individuals with COVID-19 without underlying disease in Golestan Hospital. Kermanshah New Microbes New Infect 38:100807. https://doi.org/10.1016/j.nmni.2020.100807

3. Tezcan ME, Dogan Gokce G, Sen N, Zorlutuna Kaymak N, Ozer RS (2020) Baseline electrolyte abnormalities would be related to poor prognosis in hospitalized coronavirus disease 2019 patients. New Microbes and New Infect 37:100753-100753. https://doi.org/10.1016/j.nmni.2020.100753

4. Chen D, Li X, Song Q, Hu C, Su F, Dai J, Ye Y, Huang J, Zhang $X$ (2020) Assessment of hypokalemia and clinical characteristics in patients with coronavirus disease 2019 in Wenzhou, China. JAMA Netw Open 3:e2011122-e2011122. https://doi. org/10.1001/jamanetworkopen.2020.11122

5. Moreno-P O, Leon-Ramirez J-M, Fuertes-Kenneally L, Perdiguero M, Andres M, Garcia-Navarro M, Ruiz-Torregrosa P, Boix V, Gil J, Merino E, Asensio S, Fernandez C, Candela A, del Mar GM, Sánchez R, Reus S, Ruiz P, García-Sevila R, Martínez M-Á, García-Mullor M-M, Blanes M, Guijarro J, Pascual JC, Gonzalez I, Sanso P, Ramos JM, Javaloy J, Llopis C, Coronado O, García E, Rodríguez G, Melgar P, Franco M, Lluís F, Zaragoza C, Alcaraz C, Carrión A, Villodre C, de la Cuesta ER, Alenda C, Peiró F, Planelles M, Greco L, Silvia S, Francia A, Verdú I, Sales J, Palacios A, Ballester H, GarcíaValentín A, Márquez M, Canelo E, Juan A, Vives E, Revert A, Fuente G, Nofuentes E, Mangas C, Vera E, Ferradas A, López H, Herrera C, López B, Morillas M, Rodríguez V, Khartabil M, Giménez M, Tovar E, Martínez E, Medina L, Baile S, Salazar C, Guerra N, Moliner S, López-González M-C, Figueres B (2020) Hypokalemia as a sensitive biomarker of disease severity and the requirement for invasive mechanical ventilation requirement in COVID-19 pneumonia: a case series of 306 mediterranean patients. Int J Infect Dis 100:449-454. https://doi.org/10.1016/j. ijid.2020.09.033

6. Liu S, Zhang L, Weng H, Yang F, Jin H, Fan F, Zheng X, Yang H, Li H, Zhang Y, Li J (2021) Association between average plasma potassium levels and 30-day mortality during hospitalization in patients with COVID-19 in Wuhan, China. Int J Med Sci 18:736743. https://doi.org/10.7150/ijms.50965

7. Huang Y, Yang C, Xu X-f, Xu W, Liu S-w (2020) Structural and functional properties of SARS-CoV-2 spike protein: potential antivirus drug development for COVID-19. Acta Pharmacol Sin 41:1141-1149. https://doi.org/10.1038/s41401-020-0485-4

8. Yan R, Zhang Y, Li Y, Xia L, Guo Y, Zhou Q (2020) Structural basis for the recognition of SARS-CoV-2 by full-length human ACE2. Science 367:1444-1448. https://doi.org/10.1126/science. abb2762

9. Yang T, Xu C (2017) Physiology and pathophysiology of the intrarenal renin-angiotensin system: an update. J Am Soc Nephrol 28:1040-1049. https://doi.org/10.1681/asn.2016070734

10. Simões e Silva AC, Lanza K, Palmeira VA, Costa LB, Flynn JT (2020) 2020 Update on the renin-angiotensin-aldosterone system in pediatric kidney disease and its interactions with coronavirus. Pediatr Nephrol. https://doi.org/10.1007/s00467-020-04759-1

11. Balla T, Baukal AJ, Eng S, Catt KJ (1991) Angiotensin II receptor subtypes and biological responses in the adrenal cortex and medulla. Mol Pharmacol 40:401-406

12. Kuba K, Imai Y, Rao S, Gao H, Guo F, Guan B, Huan Y, Yang P, Zhang Y, Deng W, Bao L, Zhang B, Liu G, Wang Z, Chappell M, Liu Y, Zheng D, Leibbrandt A, Wada T, Slutsky AS, Liu D, Qin C, Jiang C, Penninger JM (2005) A crucial role of angiotensin converting enzyme 2 (ACE2) in SARS coronavirus-induced lung injury. Nat Med 11:875-879. https://doi.org/10.1038/nm1267

13. Norwood VF, Craig MR, Harris JM, Gomez RA (1997) Differential expression of angiotensin II receptors during early renal morphogenesis. Am J Physiol-Regul, Integr Comp Physiol 272:R662R668. https://doi.org/10.1152/ajpregu.1997.272.2.R662 
14. Tipnis SR, Hooper NM, Hyde R, Karran E, Christie G, Turner AJ (2000) A human homolog of angiotensin-converting enzyme: cloning and functional expression as a captopril-insensitive carboxypeptidase*. J Biol Chem 275:33238-33243. https://doi.org/ 10.1074/jbc.M002615200

15. Shefer G, Marcus Y, Knoll E, Dolkart O, Foichtwanger S, Nevo N, Limor R, Stern N (2016) Angiotensin 1-7 Is a negative modulator of aldosterone secretion in vitro and in vivo. Hypertension 68:378-384. https://doi.org/10.1161/HYPERTENSIONAHA.116. 07088

16. Rodrigues Prestes TR, Rocha NP, Miranda AS, Teixeira AL, Simoes ESAC (2017) The anti-inflammatory potential of ACE2/ angiotensin-(1-7)/Mas receptor axis: evidence from basic and clinical research. Curr Drug Targets 18:1301-1313. https://doi. org/10.2174/1389450117666160727142401

17. Deshotels MR, Xia H, Sriramula S, Lazartigues E, Filipeanu CM (2014) Angiotensin II mediates angiotensin converting enzyme type 2 internalization and degradation through an angiotensin II type I receptor-dependent mechanism. Hypertension 64:13681375. https://doi.org/10.1161/hypertensionaha.114.03743

18. Muhanna D, Arnipalli SR, Kumar SB, Ziouzenkova O (2020) Osmotic adaptation by $\mathrm{Na}(+)$-dependent transporters and ACE2: correlation with hemostatic crisis in COVID-19. Biomedicines. https://doi.org/10.3390/biomedicines8110460

19. Zou X, Chen K, Zou J, Han P, Hao J, Han Z (2020) Single-cell RNA-seq data analysis on the receptor ACE2 expression reveals the potential risk of different human organs vulnerable to 2019nCoV infection. Front Med 14:185-192. https://doi.org/10.1007/ s11684-020-0754-0

20. Hanukoglu I, Hanukoglu A (2016) Epithelial sodium channel $(\mathrm{ENaC})$ family: phylogeny, structure-function, tissue distribution, and associated inherited diseases. Gene 579:95-132. https://doi. org/10.1016/j.gene.2015.12.061

21. Alvarez de la Rosa D, Li H, Canessa CM (2002) Effects of aldosterone on biosynthesis, traffic, and functional expression of epithelial sodium channels in A6 cells. J Gen Physiol 119:427-442. https://doi.org/10.1085/jgp.20028559

22. Zaika O, Mamenko M, Staruschenko A, Pochynyuk O (2013) Direct activation of ENaC by angiotensin II: recent advances and new insights. Curr Hypertens Rep 15:17-24. https://doi.org/10. 1007/s11906-012-0316-1

23. Clase CM, Carrero J-J, Ellison DH, Grams ME, Hemmelgarn BR, Jardine MJ, Kovesdy CP, Kline GA, Lindner G, Obrador GT, Palmer BF, Cheung M, Wheeler DC, Winkelmayer WC, PecoitsFilho R, Ashuntantang GE, Bakker SJL, Bakris GL, Bhandari S, Burdmann EA, Campbell KL, Charytan DM, Clegg DJ, Cuppari L, Goldsmith D, Hallan SI, He J, Herzog CA, Hoenig MP, Hoorn EJ, Leipziger JG, Leonberg-Yoo AK, Lerma EV, Lopez-Almaraz JE, Małyszko J, Mann JFE, Marklund M, McDonough AA, Nagahama M, Navaneethan SD, Pitt B, Pochynyuk OM, Proença de Moraes T, Rafique Z, Robinson BM, Roger SD, Rossignol P, Singer AJ, Smyth A, Sood MM, Walsh M, Weir MR, Wingo CS (2020) Potassium homeostasis and management of dyskalemia in kidney diseases: conclusions from a kidney disease: improving global outcomes (KDIGO) controversies conference. Kidney Int 97:42-61. https://doi.org/10.1016/j.kint.2019.09.018

24. Hoffmann M, Kleine-Weber H, Schroeder S, Krüger N, Herrler T, Erichsen S, Schiergens TS, Herrler G, Wu NH, Nitsche A, Müller MA, Drosten C, Pöhlmann S (2020) SARS-CoV-2 cell entry depends on ACE2 and TMPRSS2 and is blocked by a clinically proven protease inhibitor. Cell 181:271-280.e8. https://doi.org/10. 1016/j.cell.2020.02.052

25. Shen L-W, Qian M-Q, Yu K, Narva S, Yu F, Wu Y-L, Zhang W (2020) Inhibition of influenza A virus propagation by benzoselenoxanthenes stabilizing TMPRSS2 Gene G-quadruplex and hence down-regulating TMPRSS2 expression. Sci Rep 10:7635. https:// doi.org/10.1038/s41598-020-64368-8

26. Donaldson SH, Hirsh A, Li DC, Holloway G, Chao J, Boucher RC, Gabriel SE (2002) Regulation of the epithelial sodium channel by serine proteases in human airways. J Biol Chem 277:8338-8345. https://doi.org/10.1074/jbc.M105044200

27. de Rivero Vaccari JC, Dietrich WD, Keane RW, de Rivero Vaccari JP (2020) The inflammasome in times of COVID-19. Front Immunol. https://doi.org/10.3389/fimmu.2020.583373

28. Mehta P, McAuley DF, Brown M, Sanchez E, Tattersall RS, Manson JJ (2020) COVID-19: consider cytokine storm syndromes and immunosuppression. The Lancet 395:1033-1034

29. Pétrilli V, Papin S, Dostert C, Mayor A, Martinon F, Tschopp J (2007) Activation of the NALP3 inflammasome is triggered by low intracellular potassium concentration. Cell Death Differ 14:1583-1589. https://doi.org/10.1038/sj.cdd.4402195

30. Makabe H, Kojika M, Takahashi G, Matsumoto N, Shibata S, Suzuki Y, Inoue Y, Endo S (2012) Interleukin-18 levels reflect the long-term prognosis of acute lung injury and acute respiratory distress syndrome. J Anesth 26:658-663. https://doi.org/10.1007/ s00540-012-1409-3

31. Kuipers MT, Aslami H, Janczy JR, van der Sluijs KF, Vlaar AP, Wolthuis EK, Choi G, Roelofs JJ, Flavell RA, Sutterwala FS, Bresser P, Leemans JC, van der Poll T, Schultz MJ, Wieland CW (2012) Ventilator-induced lung injury is mediated by the NLRP3 inflammasome. Anesthesiology 116:1104-1115. https://doi.org/ 10.1097/ALN.0b013e3182518bc0

32. Qiao J, Wu X, Luo Q, Wei G, Xu M, Wu Y, Liu Y, Li X, Zi J, Ju W, Fu L, Chen C, Wu Q, Zhu S, Qi K, Li D, Li Z, Andrews RK, Zeng L, Gardiner EE, Xu K (2018) NLRP3 regulates platelet integrin $\alpha \mathrm{IIb} \beta 3$ outside-in signaling, hemostasis and arterial thrombosis. Haematologica 103:1568-1576. https://doi.org/10. 3324/haematol.2018.191700

33. Rodrigues TS, de Sá KSG, Ishimoto AY, Becerra A, Oliveira S, Almeida L, Gonçalves AV, Perucello DB, Andrade WA, Castro R, Veras FP, Toller-Kawahisa JE, Nascimento DC, de Lima MHF, Silva CMS, Caetite DB, Martins RB, Castro IA, Pontelli MC, de Barros FC, Amaral NB, Giannini MC, Bonjorno LP, Lopes MIF, Santana RC, Vilar FC, Auxiliadora-Martins M, Luppino-Assad R, Almeida SCL, Oliveira FR, Batah SS, Siyuan L, Benatti MN, Cunha TM, Alves-Filho JC, Cunha FQ, Cunha LD, Frantz FG, Kohlsdorf T, Fabro AT, Arruda E, Oliveira RDR, Louzada-Junior $P$, Zamboni DS (2021) Inflammasomes are activated in response to SARS-CoV-2 infection and are associated with COVID-19 severity in patients. J Exp Med 218:e20201707. https://doi.org/ 10.1084/jem.20201707

34. Scambler T, Jarosz-Griffiths HH, Lara-Reyna S, Pathak S, Wong C, Holbrook J, Martinon F, Savic S, Peckham D, McDermott MF (2019) ENaC-mediated sodium influx exacerbates NLRP3dependent inflammation in cystic fibrosis. eLife 8:e49248. https:// doi.org/10.7554/eLife.49248

35. Örd M, Faustova I, Loog M (2020) The sequence at Spike S1/S2 site enables cleavage by furin and phospho-regulation in SARSCoV2 but not in SARS-CoV1 or MERS-CoV. Sci Rep 10:16944. https://doi.org/10.1038/s41598-020-74101-0

36. Johnson BA, Xie X, Bailey AL, Kalveram B, Lokugamage KG, Muruato A, Zou J, Zhang X, Juelich T, Smith JK, Zhang L, Bopp N, Schindewolf C, Vu M, Vanderheiden A, Winkler ES, Swetnam D, Plante JA, Aguilar P, Plante KS, Popov V, Lee B, Weaver SC, Suthar MS, Routh AL, Ren P, Ku Z, An Z, Debbink K, Diamond MS, Shi P-Y, Freiberg AN, Menachery VD (2021) Loss of furin cleavage site attenuates SARS-CoV-2 pathogenesis. Nature 591:293-299. https://doi.org/10.1038/s41586-021-03237-4

37. Wu C, Zheng M, Yang Y, Gu X, Yang K, Li M, Liu Y, Zhang Q, Zhang P, Wang Y, Wang Q, Xu Y, Zhou Y, Zhang Y, Chen L, 
Li H (2020) Furin: a potential therapeutic target for COVID-19. iScience 23:101642. https://doi.org/10.1016/j.isci.2020.101642

38. Carattino MD, Sheng S, Bruns JB, Pilewski JM, Hughey RP, Kleyman TR (2006) The epithelial $\mathrm{Na}+$ channel is inhibited by a peptide derived from proteolytic processing of its alpha subunit. J Biol Chem 281:18901-18907. https://doi.org/10.1074/jbc.M6041 09200

39. Anand P, Puranik A, Aravamudan M, Venkatakrishnan AJ, Soundararajan V (2020) SARS-CoV-2 strategically mimics proteolytic activation of human ENaC. eLife 9:e58603. https://doi.org/10. 7554/eLife.58603

40. Szabó GT, Kiss A, Csanádi Z, Czuriga D (2020) Hypothetical dysfunction of the epithelial sodium channel may justify neurohumoral blockade in coronavirus disease 2019. ESC Heart Fail. https://doi.org/10.1002/ehf2.13078

41. Boiko N, Kucher V, Stockand JD (2015) Pseudohypoaldosteronism type 1 and Liddle's syndrome mutations that affect the singlechannel properties of the epithelial $\mathrm{Na}+$ channel. Physiol Rep. https://doi.org/10.14814/phy2.12600

42. Matalon S, Bartoszewski R, Collawn JF (2015) Role of epithelial sodium channels in the regulation of lung fluid homeostasis. Am J Physiol-Lung Cell Mol Physiol 309:L1229-L1238. https://doi. org/10.1152/ajplung.00319.2015

43. Zhang H, Penninger JM, Li Y, Zhong N, Slutsky AS (2020) Angiotensin-converting enzyme 2 (ACE2) as a SARS-CoV-2 receptor: molecular mechanisms and potential therapeutic target. Intensive Care Med 46:586-590. https://doi.org/10.1007/ s00134-020-05985-9

44. Zoufaly A, Poglitsch M, Aberle JH, Hoepler W, Seitz T, Traugott M, Grieb A, Pawelka E, Laferl H, Wenisch C, Neuhold S, Haider D, Stiasny K, Bergthaler A, Puchhammer-Stoeckl E, Mirazimi A, Montserrat N, Zhang H, Slutsky AS, Penninger JM (2020) Human recombinant soluble ACE2 in severe COVID-19. Lancet Respir Med 8:1154-1158. https://doi.org/10.1016/s2213-2600(20) 30418-5

45. Alhenc-Gelas F, Drueke TB (2020) Blockade of SARS-CoV-2 infection by recombinant soluble ACE2. Kidney Int 97:10911093. https://doi.org/10.1016/j.kint.2020.04.009

46. Jankun J (2020) COVID-19 pandemic; transmembrane protease serine 2 (TMPRSS2) inhibitors as potential therapeutics for SARS-CoV-2 coronavirus. Translation 7:1-5. https://doi.org/10. 4570/utjms.vol7-2020-361 (Corresponding author(s))
47. Hoffmann M, Hofmann-Winkler H, Smith JC, Krüger N, Arora P, Sørensen LK, Søgaard OS, Hasselstrøm JB, Winkler M, Hempel T, Raich L, Olsson S, Danov O, Jonigk D, Yamazoe T, Yamatsuta K, Mizuno H, Ludwig S, Noé F, Kjolby M, Braun A, Sheltzer JM, Pöhlmann S (2021) Camostat mesylate inhibits SARS-CoV-2 activation by TMPRSS2-related proteases and its metabolite GBPA exerts antiviral activity. EBioMedicine. https://doi.org/10.1016/j. ebiom.2021.103255

48. Maekawa A, Kakizoe Y, Miyoshi T, Wakida N, Ko T, Shiraishi N, Adachi M, Tomita K, Kitamura K (2009) Camostat mesilate inhibits prostasin activity and reduces blood pressure and renal injury in salt-sensitive hypertension. J Hypertens 27:181-189. https://doi.org/10.1097/hjh.0b013e328317a762

49. Uchimura K, Kakizoe Y, Onoue T, Hayata M, Morinaga J, Yamazoe R, Ueda M, Mizumoto T, Adachi M, Miyoshi T, Shiraishi N, Sakai Y, Tomita K, Kitamura K (2012) In vivo contribution of serine proteases to the proteolytic activation of $\gamma \mathrm{ENaC}$ in aldosterone-infused rats. Am J Physiol-Ren Physiol 303:F939-F943. https://doi.org/10.1152/ajprenal.00705.2011

50. Kitamura K, Tomita K (2010) Regulation of renal sodium handling through the interaction between serine proteases and serine protease inhibitors. Clin Exp Nephrol 14:405-410. https://doi.org/ 10.1007/s10157-010-0299-7

51. Ansarin K, Tolouian R, Ardalan M, Taghizadieh A, Varshochi M, Teimouri S, Vaezi T, Valizadeh H, Saleh P, Safiri S, Chapman KR (2020) Effect of bromhexine on clinical outcomes and mortality in COVID-19 patients: a randomized clinical trial. Bioimpacts 10:209-215. https://doi.org/10.34172/bi.2020.27

52. Wu C, Zheng M, Yang Y, Gu X, Yang K, Li M, Liu Y, Zhang Q, Zhang P, Wang Y (2020) Furin: a potential therapeutic target for COVID-19. iScience 23:1042

53. Douglas LEJ, Reihill JA, Ho MW-Y, Axten JM, Martin SL (2019) Furin inhibition as a mechanism to reduce aberrant ENaC-mediated sodium transport and rehydrate the airways in cystic fibrosis lung disease. FASEB J 33:802.26-802.26. https://doi.org/10.1096/ fasebj.2019.33.1_supplement.802.26

Publisher's Note Springer Nature remains neutral with regard to jurisdictional claims in published maps and institutional affiliations. 